\title{
Toxic Effect of Manganese on Growth and Sporulation of Bacillus stearothermophilus
}

\author{
By HON YEUNG CHEUNG, † LJUBIŠA VITKOVIĆ† AND \\ MICHAEL R. W. BROW N* \\ Microbiology Research Group, Department of Pharmacy, University of Aston in Birmingham, \\ Birmingham B4 7ET, U.K.
}

(Received 11 December 1981)

\begin{abstract}
The growth rate of Bacillus stearothermophilus cells in a chemically defined medium was inversely proportional to the concentration of $\mathrm{Mn}^{2+}$ between 15 and $300 \mu \mathrm{M}$. In the presence of $>100 \mu \mathrm{M}-$ $\mathrm{Mn}^{2+}$, cells grew with doubling times of $>60 \mathrm{~min}$. Cessation of exponential growth due to a high concentration of $\mathrm{Mn}^{2+}$ was most pronounced in cultures low in sulphur or carbon. This was due to the toxic effect of high $\mathrm{Mn}^{2+}$ concentrations since dilution of cultures to a final $\mathrm{Mn}^{2+}$ concentration of $15 \mu \mathrm{M}$ or less restored the growth rate to maximum. Sporulation depended upon the nature of the growth-limiting nutrient. The manganese effect on sporulation of sulphurlimited cells depended upon the concentration of glucose and the aeration rate in a qualitatively similar manner. The highest spore yield at optimal aeration rates was obtained when the initial $\mathrm{Mn}^{2+}$ concentration in the medium was 10-30 $\mu \mathrm{M}$. Although the growth rate of bacteria in lowsulphate media was determined by the manganese concentration, its effect on sporulation frequency was independent of the growth rate.
\end{abstract}

\section{INTRODUCTION}

The properties of vegetative cells and spores of bacteria are determined by the conditions in which they are grown. Nutrient limitation and growth rate influence the gross cellular composition and properties of various Gram-positive and Gram-negative bacteria grown in batch or continuous culture (Tempest, 1969; Meers \& Tempest, 1970; Dean, 1972; Holme, 1972; Gilbert $\&$ Brown, $1978 a, b)$. Several characteristic properties of bacterial spores are dependent upon the nature of the medium component limiting vegetative growth (Brown \& Hodges, 1974; Hodges \& Brown, 1975; Lee \& Brown, 1975). The nature of the limiting component has rarely been specified for many of the published defined media (Anderson \& Friesen, 1972; Rowe et al., 1975). Likewise, the degree of excess of non-limiting components, aeration and growth rates have received little consideration. Commercial media vary in their metal ion content with significant effects on microbial growth (Bovallius \& Zacharias, 1971). Consequently, conflicting reports abound describing the requirements and the effect of various divalent cations on growth and sporulation of Bacillus species. Anderson \& Friesen (1972) reported that the concentration of manganese $(100 \mu \mathrm{M})$ required for maximum sporulation of Bacillus stearothermophilus in a chemically defined medium was significantly greater than the amount required for vegetative growth. In contrast, Rowe et al. (1975) reported for the same species that manganese 'is required in such trace amounts that it need not be added to the defined media'. In light of the absolute manganese requirement for sporulation of Bacillus species (Charney et al., 1951) and its regulatory role in the establishment and maintenance of dormancy (Vasantha \& Freese, 1979), it is of great importance to define precisely the influence of manganese on growth and sporulation as nutritional conditions change.

+ Present address: Laboratory of Molecular Biology, National Institute of Neurological and Communicative Disorders and Stroke, Bethesda, Maryland 20205, U.S.A. 


\section{METHODS}

Organism and growth media. Bacillus stearothermophilus NCTC 10003 was kindly provided by Dr R. A. Anderson. Spore stock suspension was prepared by plating the cells on $0.5 \%$ glucose $/ 1 \%$ tryptone agar and harvesting the spores after $96 \mathrm{~h}$ incubation at $60^{\circ} \mathrm{C}$ (Long \& Williams, 1958). Spores were washed, resuspended at $10^{9}$ spores $\mathrm{ml}^{-1}$ in phosphate buffered saline $\left(5 \mathrm{~mm}, \mathrm{pH} \mathrm{7 \cdot 2)}\right.$ and stored at $4{ }^{\circ} \mathrm{C}$ until used. Chemically defined medium (CDM) contained 17.6 mM- $\mathrm{Na}_{2} \mathrm{HPO}_{4}, 2.4 \mathrm{mM}$-Lk-glutamate, 7.3 mM-KH $\mathrm{PO}_{4}, 7.5 \mathrm{~mm}$-D-glucose, $9.35 \mathrm{~mm}$ $\mathrm{NH}_{4} \mathrm{Cl}, 0.1 \mathrm{~mm}-\mathrm{CaCl}_{2}, 0.1 \mathrm{~mm}-\mathrm{Na}_{2} \mathrm{SO}_{4}, 0.5 \mathrm{~mm}-\mathrm{MgCl}_{2}, 10 \mu \mathrm{M}-\mathrm{FeCl}_{2}$ and $10 \mu \mathrm{M}-\mathrm{MnCl}_{2}$. This medium supports maximum growth to a turbidity at $470 \mathrm{~nm}$ of $2 \cdot 0$, at which time the culture becomes oxygen-limited. In the experiments involving specific nutrient limitation the concentration of the limiting nutrient was lower than stated here. $\mathrm{Mn}^{2+}$ concentration (see below) was varied as indicated in the figures. All other data refer to final concentrations of added nutrients. All components were autoclaved as stock solutions. No precipitation was observed after constitution of the medium and adjustment of the $\mathrm{pH}$ to $7 \cdot 2$.

Chemicals and glassware. All chemicals used in the preparation of CDM were analytical grade reagents (Analar) except $\mathrm{FeCl}_{2}, 4 \mathrm{H}_{2} \mathrm{O}$ which was laboratory reagent grade. Deionized, double-distilled water was used throughout. Glassware was soaked overnight in $5 \%(\mathrm{v} / \mathrm{v})$ Decon $90(\mathrm{BDH})$, rinsed and soaked further in $1 \%(\mathrm{v} / \mathrm{v}) \mathrm{HCl}$, and rinsed repeatedly in water before drying.

Growth conditions and measurements. Cultures $(25 \mathrm{ml})$ in $100 \mathrm{ml}$ Erlenmeyer flasks were incubated at $60^{\circ} \mathrm{C}$ with shaking at 110 throws $\mathrm{min}^{-1}$. Growth was measured as turbidity at $470 \mathrm{~nm}\left(A_{470}\right)$ using a Unicam SP600 spectrophotometer with $1 \mathrm{~cm}$ light path cuvettes. The measurements were corrected for the non-linearity of turbidity readings (Lawer \& Maier, 1977). Exponentially growing cells subcultured twice in a final medium of choice were used as inocula such that the initial $A_{470}$ was $0 \cdot 02-0 \cdot 04$. Growth curves were recorded for cultures containing graded concentrations of a limiting nutrient keeping all other conditions constant (Brown \& Hodges, 1974). Growth rate and the $A_{470}$ at the transition point between the exponential and stationary growth phase were determined from these growth curves.

Sporulation. Bacteria were cultured as in the growth limitation experiments except that the culture volumes were $500 \mathrm{ml}$ in fermenters with adjustable aeration. Sporulation ensued at various times after the end of exponential growth. Spores were counted $20 \mathrm{~h}$ after the inoculation of the medium as described previously (Brown \& Hodges, 1974).

Manganese assay. Culture samples of $20 \mathrm{ml}$ were removed at hourly intervals and centrifuged for $20 \mathrm{~min}$ at $19000 \mathrm{~g}$. The cell-free supernatant was then transferred to acid-cleaned test tubes and the manganese concentration was determined using a Unicam SP90 atomic absorption spectrophotometer. The instrument was calibrated before each run according to the manufacturer's specifications. Contaminating levels of manganese measured by a more sensitive instrument (Perkin Elmer 560 flameless spectrophotometer) in complete CDM without added $\mathrm{Mn}^{2+}$ were less than $10^{-7} \mathrm{M}$.

\section{RESULTS}

\section{Growth and nutrient limitation}

Bacillus stearothermophilus cells were grown as a batch culture in $\mathrm{CDM}$ at $60^{\circ} \mathrm{C}, \mathrm{pH} 7.2$ with optimal aeration. Depletion of any one nutrient, others being in excess, reduced exponential growth and derepressed sporulation. Transition from exponential growth to the stationary phase was rapid when glucose or nitrogen was limiting. With limiting amounts of other nutrients the transition was more gradual (data not shown). The cells for nutrient limitation studies were initially grown in the presence of $100 \mu \mathrm{M}-\mathrm{Mn}^{2+}$ (Anderson \& Friesen, 1972; Rowe et al., 1975). The transition point, i.e. the cell density (measured as $A_{470}$ ) at which the growth rate started to decrease, was plotted as a function of limiting nutrient concentration (Fig. 1). In all cases studied, the transition point increased linearly with increasing concentration of the limiting nutrient up to a maximum concentration above which the nutrient did not limit growth. In cultures of sulphur- and carbon-limited cells (Fig. $1 a, b$ ) the transition point occurred at much lower cell densities than in cultures of magnesium- and nitrogen-limited cells (Fig. $1 c, d$ ). This difference was not observed when the $\mathrm{Mn}^{2+}$ concentration in the medium was lowered to $10 \mu \mathrm{M}$ (Fig. $1 a, b$ ). Thus, the growth of $B$. stearothermophilus cells, as reflected by the transition point, appeared to be inhibited by $100 \mu \mathrm{M}-\mathrm{Mn}^{2+}$. This effect was pronounced in sulphur-limited cultures in which it was further investigated.

\section{Manganese and growth}

As the $\mathrm{Mn}^{2+}$ concentration in CDM was increased from 0 to $10 \mu \mathrm{M}$ the cell density at the transition point increased proportionally, indicating that the cells were depleted of manganese 

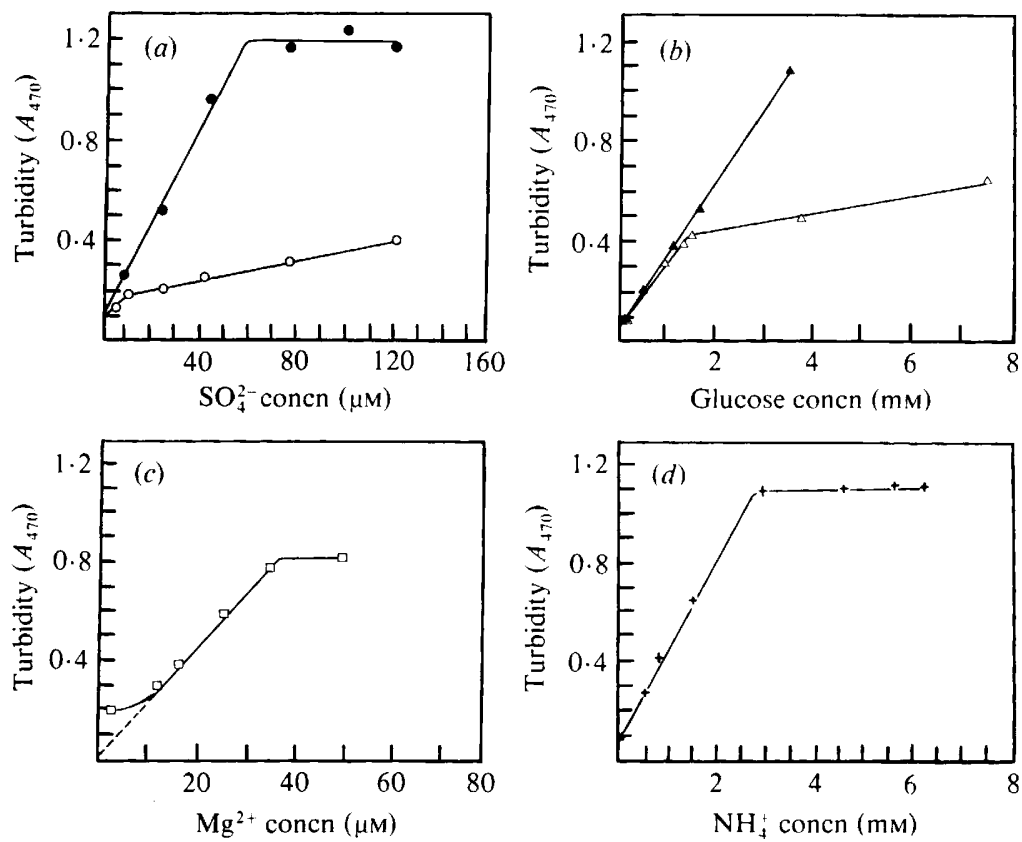

Fig. 1. Effect of nutrient limitation on the growth of B. stearothermophilus. Cells were grown in CDM containing $100 \mu \mathrm{M}-\mathrm{Mn}^{2+}$ at $60^{\circ} \mathrm{C}$ with vigorous aeration. The maximum cell concentration at the transition from the exponential to the stationary growth phase was measured as turbidity at $470 \mathrm{~nm}$ $\left(A_{470}\right)$. Balanced growth was limited by the concentration of the sulphur $(a, O)$, carbon $(b, \triangle)$, magnesium $(c, \square)$ and nitrogen $(d,+)$ source. When the $\mathrm{Mn}^{2+}$ concentration in the CDM was lowered to $10 \mu \mathrm{M}$, the sulphur-limited $(a, \boldsymbol{)})$ and carbon-limited $(b, \Delta)$ cell densities approached those in magnesium-limited and nitrogen-limited cultures.

(Fig. 2). However, manganese inhibited growth at all concentration above $15 \mu \mathrm{M}$. The optimal $\mathrm{Mn}^{2+}$ concentration for growth of vegetative cells was in the narrow range between 10 and 15 $\mu \mathrm{M}$. The growth rate constant $(\mu)$ was independent of $\mathrm{Mn}^{2+}$ when present at suboptimal levels $(5-10 \mu \mathrm{M})$ and was inversely proportional to $\mathrm{Mn}^{2+}$ concentrations above $15 \mu \mathrm{M}$ (Fig. 3 ). The maximum growth rate was restored when the $\mathrm{Mn}^{2+}$ concentration in the medium was lowered to $15 \mu \mathrm{M}$ or less by dilution with fresh, $\mathrm{Mn}^{2+}$-free medium.

\section{Manganese mobility during growth and sporulation}

We investigated manganese transport in these cells by measuring its disappearance/reappearance from the medium during growth and sporulation (Fig. 4). Cells subcultured at least twice in the same medium as that to be inoculated were diluted 100-fold into CDM containing $18 \mu \mathrm{M}$ $\mathrm{Mn}^{2+}$ and with the sulphate concentration adjusted so that it eventually became growth limiting. Growth and the time course of the change in $\mathrm{Mn}^{2+}$ concentration in the medium were followed (Fig. $4 a$ ). The turbidity and $\mathrm{Mn}^{2+}$ uptake increased exponentially with time. Approximately $1 \mathrm{~h}$ after the stationary phase was reached, egression of $\mathrm{Mn}^{2+}$ followed for $3 \mathrm{~h}$ restoring the $\mathrm{Mn}^{2+}$ concentration in the medium to $25 \%$ of its initial value. The concentration again decreased during later stages of sporulation. The effect of $\mathrm{Mn}^{2+}$ starvation on transport was investigated when an overnight culture of $\mathrm{Mn}^{2+}$-starved, non-sporulating cells was diluted 100 -fold into a medium containing $18 \mu \mathrm{M}-\mathrm{Mn}^{2+}$ (Fig. $4 b$ ). The overall features of the process remained unchanged except that the rate of $\mathrm{Mn}^{2+}$ disappearance from the medium during exponential growth was approximately $30 \%$ higher when the inoculum was depleted of $\mathrm{Mn}^{2+}$. The $\mathrm{Mn}^{2+}$ concentration in the medium was below the level of detection by the time the culture reached the transition point. 


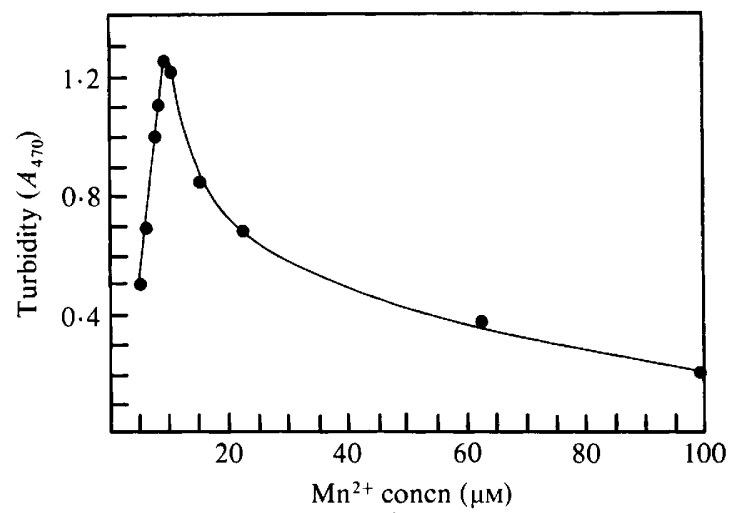

Fig. 2

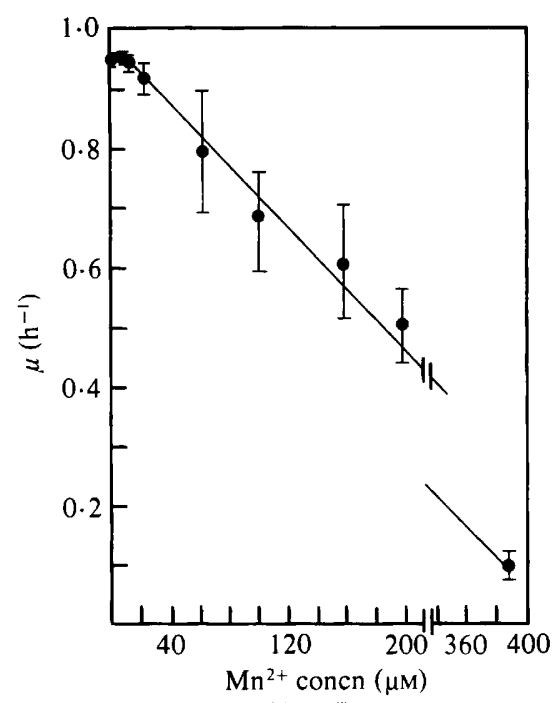

Fig. 3

Fig. 2. Manganese influence on sulphur-limited cell growth. The maximum turbidity of exponentially growing cells in CDM in the presence of $75 \mu \mathrm{M}-\mathrm{Na}_{2} \mathrm{SO}_{4}\left(A_{470}\right)$ was plotted against the initial $\mathrm{Mn}^{2+}$ concentration in the medium.

Fig. 3. Dependence of growth rate on manganese. Cells were grown in the CDM containing $41 \mu \mathrm{M}$ $\mathrm{Na}_{2} \mathrm{SO}_{4}$ and $\mathrm{Mn}^{2+}$ at the concentrations indicated, all other nutrients being in excess. The growth rate $(\mu)$ was determined as the slope of the linear portion of the growth curve. Vertical bars indicate standard errors from three independent experiments.
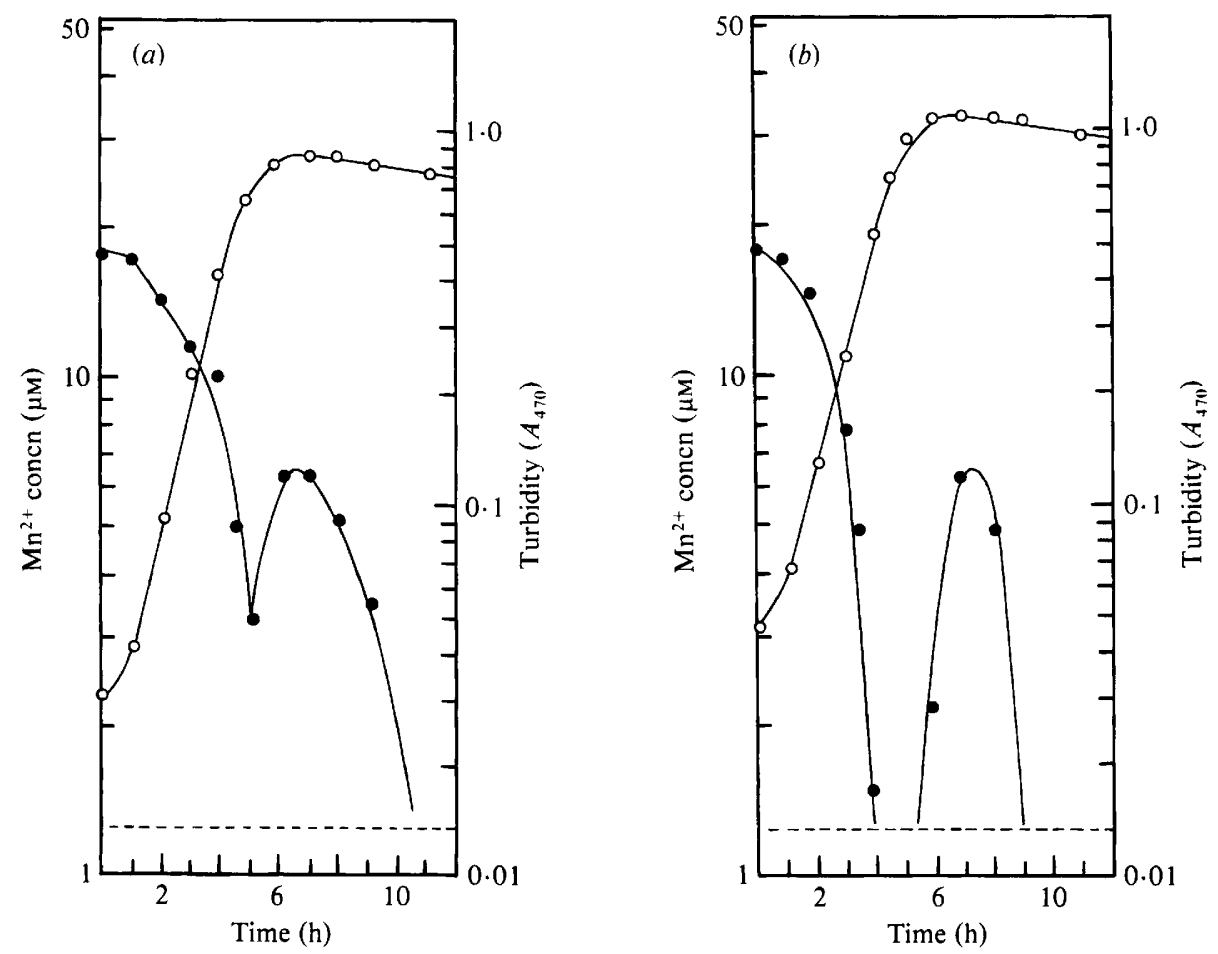

Fig. 4. Manganese levels in the medium during growth and sporulation (O). Cells were grown in the CDM containing $41 \mu \mathrm{M}-\mathrm{Na}_{2} \mathrm{SO}_{4}$ and $18 \mu \mathrm{M}-\mathrm{Mn}^{2+}$. Growth was measured as the turbidity at $470 \mathrm{~nm}$ (O). The inocula used were $(a)$ exponentially growing cells subcultured twice into the medium to be inoculated, or (b) manganese-starved cells grown in $2 \cdot 1 \mu \mathrm{M}-\mathrm{Mn}^{2+}$ to an $A_{470}$ of 2 , then washed and resuspended in $\mathrm{Mn}^{2+}$-free medium. The dashed line denotes the limit of $\mathrm{Mn}^{2+}$ detection. Supernatant assayed after $11 \mathrm{~h}(a)$ and $9 \mathrm{~h}(b)$ had no detectable manganese. 


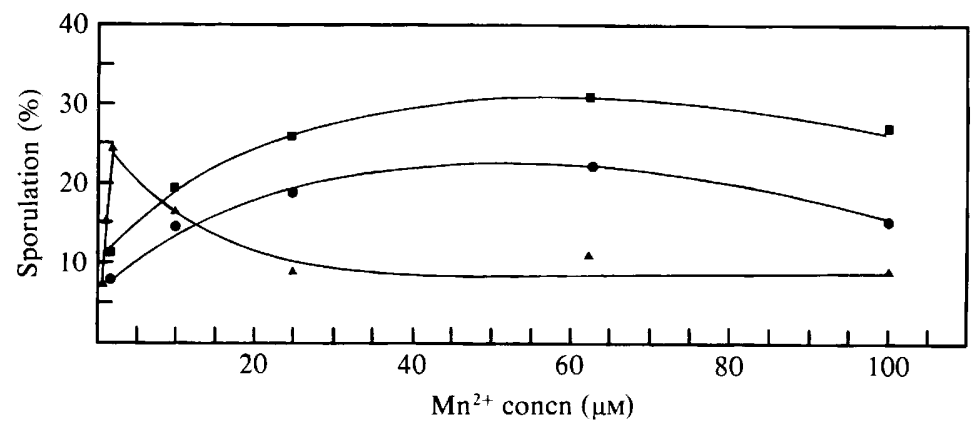

Fig. 5. Manganese influence on sporulation frequency as a function of glucose concentration in the medium. The percentage of cells yielding phase-bright spores after $20 \mathrm{~h}$ incubation in media containing $1.50(\triangle), 3.75(\square)$ and $7.50(0)$ mM-glucose was plotted against the $\mathrm{Mn}^{2+}$ concentration in the medium. All other nutrients were in excess and the aeration rate was $100 \mathrm{ml} \mathrm{min}^{-1}$.

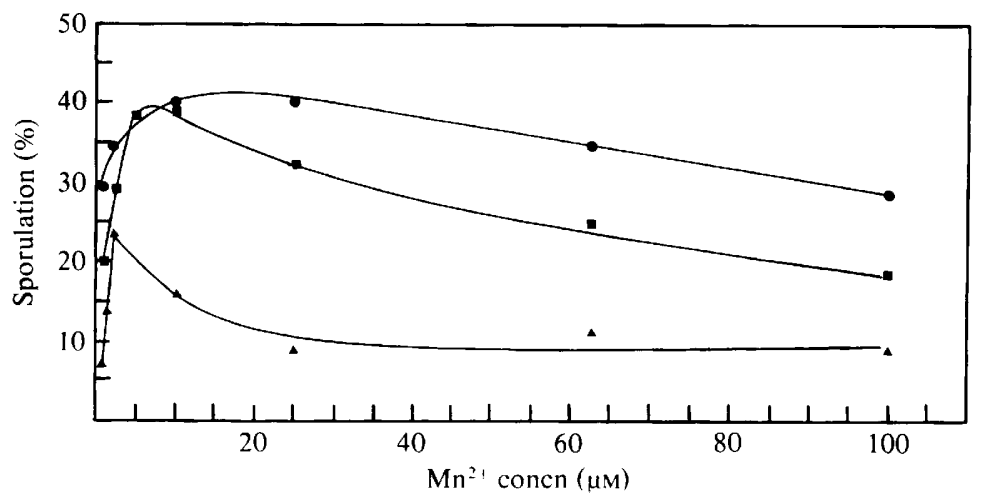

Fig. 6. Manganese influence on sporulation frequency as a function of aeration rate. The percentage of cells yielding phase-bright spores after $20 \mathrm{~h}$ incubation in media aerated at $100(\Delta), 600(\square)$ and 800 (O) $\mathrm{ml} \mathrm{min}^{-1}$ was plotted against the $\mathrm{Mn}^{2+}$ concentration in the medium. The glucose concentration in all media was $1.5 \mathrm{~mm}$ and all other nutrients were in excess.

\section{Manganese and sporulation}

The ability of cells to sporulate was assessed by counting phase-bright spores after $20 \mathrm{~h}$ incubation. This number was expressed as a percentage of the total number of cells plus spores present (sporulation frequency). Initial nutritional conditions at the time of inoculation were specified. We were interested in elucidating how the initial environmental conditions during vegetative growth affected the capacity of cells to sporulate. This appeared to be a closer approximation to the slowly changing ecological situation than that provided by the replacement technique (Sterlini \& Mandelstam, 1969). The tendency of B. stearothermophilus cells to sporulate depended on the nature of the nutrient limiting growth. With $62.5 \mu \mathrm{M}-\mathrm{Mn}^{2+}$ and an aeration rate of $800 \mathrm{ml} \mathrm{min} \mathrm{m}^{-1}, 40 \%$ of carbon- and sulphur-limited cells formed spores, while simultaneous depletion of magnesium in addition to carbon resulted in only $18 \%$ spore incidence. Under the same conditions $22 \%$ of nitrogen-limited cells yielded spores. The effect of manganese on the ability of sulphur-limited cells to sporulate was investigated by varying either the glucose concentration or the aeration rate. When the aeration rate was $100 \mathrm{ml} \mathrm{min} \mathrm{m}^{-1}$, the initial manganese concentration optimum for sporulation increased as glucose ceased to be growth limiting (Fig. 5). The differences between the curves in Fig. 5 corresponding to $1.50 \mathrm{mM}$ glucose, on one hand, and 3.75 and $7.50 \mathrm{~mm}$, on the other hand, were due to $1.50 \mathrm{~mm}$-glucose causing carbon limitation of growth before the onset of sulphur limitation. By comparing the results for the cells in media containing 3.75 and $7.50 \mathrm{~mm}$-glucose with those for the cells in media containing $1.50 \mathrm{mM}$, it is apparent that the former were less dependent on manganese for sporulation and the optimum range was less defined above $10 \mu \mathrm{M}$, i.e. the curves broadened. The inhibitory effect of manganese on sporulation was partly overcome by increased levels of glucose 


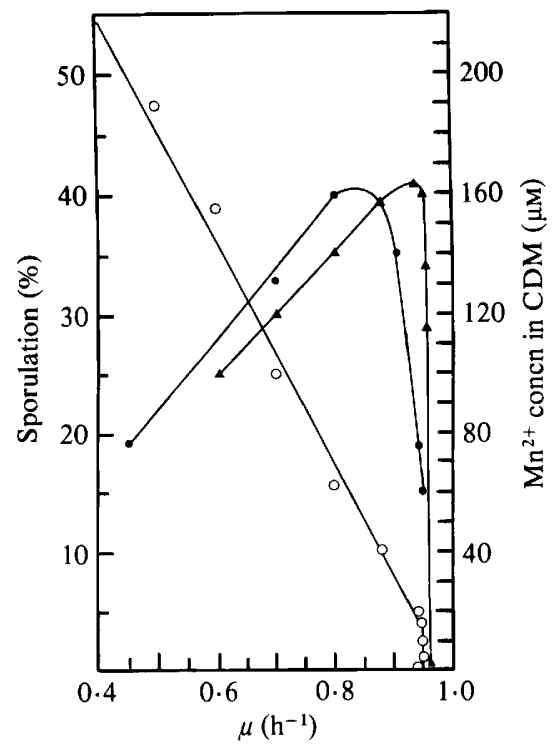

Fig. 7. Relationship between sporulation frequency and growth rate. The percentage of cells yielding phase-bright spores after $20 \mathrm{~h}$ incubation in media containing $1.50(\boldsymbol{\Delta})$ or $7.50(\mathbf{O}) \mathrm{mM}$-glucose was plotted against growth rate. The aeration rate was $800 \mathrm{ml} \mathrm{min}^{-1}$. Growth rates were dependent on the $\mathrm{Mn}^{2+}$ concentration in the medium: they were calculated from the plot $\mu$ versus $\mathrm{Mn}^{2+}(\mathrm{O})$ for this set of experiments and presented here for reference only.

(Fig. 5). These observations probably reflect the effect of the metabolic state of vegetative cells on sporulation. Optimizing the aeration rate and keeping the glucose levels at $1.50 \mathrm{~mm}$ produced qualitatively similar results (Fig. 6). Increasing the oxygen supply partly counteracted the inhibition of sporulation by manganese. More manganese was needed for sporulation as the aeration rate increased. The highest spore yield at high aeration rates was obtained when the initial $\mathrm{Mn}^{2+}$ concentration in the medium was $10-30 \mu \mathrm{M}$. We note that the functional dependences of maximum growth yield (Fig. 2) and sporulation frequency (Figs 5 and 6) on manganese concentration were qualitatively similar, i.e. an initial linear increase and a sharp maximum, followed by a decrease over a wide range of increasing $\mathrm{Mn}^{2+}$ concentrations. Figure 7 depicts the tendency of cells grown at different rates to form spores under the optimal aeration rate and in the presence of 1.50 and $7.50 \mathrm{~mm}$-glucose. This is a composite of the data presented in Figs 3 and 6. Decrease in growth rate partly compensated the catabolite-repressing effect of glucose on sporulation.

\section{DISCUSSION}

Bacillus stearothermophilus cells required manganese for growth and sporulation in the chemically defined medium. The manganese effect depended in part on the nature and concentration of growth-limiting nutrients and on the aeration rate. The optimum $\mathrm{Mn}^{2+}$ concentration for growth was $10-15 \mu \mathrm{M}$. When both growth and sporulation are considered, however, the optimum $\mathrm{Mn}^{2+}$ concentration was 10-30 $\mu \mathrm{M}$ over a range of other environmental conditions. Manganese transport by $B$. stearothermophilus cells appeared similar to the transport of this cation by Bacillus megaterium (Krueger \& Kolodziej, 1977) and Bacillus subtilis cells (Fisher et al., 1973). It seems probable that the characteristics of the manganese transport system may be similar for Bacillus species in general. Turbidity and manganese uptake increased exponentially with time. The initial uptake was followed by an efflux as the culture entered the stationary phase. At low concentrations manganese was accumulated by an active transport system and manganese-starved cells were hyperactive transporters of manganese. Cells regulate the extent of accumulation of manganese by decreasing the maximum uptake velocity during growth in 
excess manganese. The efflux rate remains constant (Eisenstadt et al., 1973). At high concentrations $(>15 \mu \mathrm{M})$ manganese enters the cells as a low affinity substrate for magnesium and/or calcium transport systems. Manganese inhibits calcium influx in B. stearothermophilus and promotes the exchange of accumulated ${ }^{45} \mathrm{Ca}$ (Stahl, 1978). Thus, in the presence of excessive concentrations, the cells accumulate manganese via primary and secondary transport systems. Inhibitors of RNA and protein synthesis prevent the reduction of the high rate of manganese uptake (Fisher et al., 1973). Similar inhibition of RNA and protein synthesis also occurs when high intracellular levels of manganese are reached. Manganese therefore appears to exert a toxic effect by such inhibition. This is consistent with the observation that the growth rate was indirectly proportional to concentrations of manganese above $15 \mu \mathrm{M}$. The growth rate is directly proportional to the number of ribosomes which, in balanced growth, is equivalent to the rate of protein synthesis (Nierlich, 1978).

The ability of $B$. stearothermophilus cells to form spores in a chemically defined medium was a multi-variate function of the initial environmental conditions preceding balanced growth. Sporulation frequency depended on the nature and concentration of a nutrient limiting growth, glucose and manganese concentrations, aeration and growth rates. The effect of manganese on sporulation appeared not to be a simple consequence of its effect on the growth of vegetative cells, as can be seen by considering Fig. 7. The growth rate was independent of manganese in the non-toxic concentration range $(5-15 \mu \mathrm{M})$ while the sporulation frequency increased sharply and linearly over the same range of concentrations. When the manganese concentration was between 15 and $60 \mu \mathrm{M}$, the growth rate decreased. In this concentration range the sporulation frequency of carbon-limited cells (grown in $1.50 \mathrm{~mm}$-glucose) decreased while that of sulphurlimited cells (grown in $7.5 \mathrm{~mm}$-glucose) increased. When the manganese concentration was $>60$ $\mu \mathrm{M}$, the sporulation frequency decreased linearly as the growth rate decreased. We conclude that manganese concentration and growth rate affect the sporulation frequency independently of each other, although the growth rate is of course a function of manganese when the latter is present at toxic levels.

\section{REFERENCES}

ANDERSON, R. A. \& Friesen, W. T. (1972). Growth and sporulation of Bacillus stearothermophilus in chemically defined media. Australian Journal of Pharmaceutical Sciences NSI, 1-6.

Bovallius, D. E. \& Zacharias, B. (1971). Variations in the metal content of some commercial media and their effect on microbial growth. Applied Microbiology 22, 260-262.

Brown, M. R. W. \& Hodges, N. A. (1974). Growth and sporulation characteristics of Bacillus megaterium under different conditions of nutrient limitation. Journal of Pharmacy and Pharmacology 26, 217227.

Charney, J., Fisher, W. P. \& Hegarty, C. P. (1951). Manganese as an essential element for sporulation in the genus Bacillus. Journal of Bacteriology 62, 145148.

DEAN, A. C. R. (1972). Influence of environment on the control of enzyme synthesis. Journal of Applied Chemistry and Biotechnology 22, 245-259.

Eisenstadt, E., Fisher, S., Der, C. L. \& Silver, S. (1973). Manganese transport in Bacillus subtilis W23 during growth and sporulation. Journal of Bacteriology 113, 1363-1372.

Fisher, S., Buxbaum, L., Toth, L., Eisenstadt, E. \& SILVER, S. (1973). Regulation of manganese accumulation and exchange in Bacillus subtilis W23. Journal of Bacteriology 113, 1373-1380.
Gilbert, P. \& Brown, M. R. W. (1978a). Effect of Rplasmid RPI and nutrient depletion on the gross cellular composition of Escherichia coli and its resistance to some uncoupling phenols. Journal of Bacteriology 133, 1062-1065.

GilberT, P. \& BROWN, M. R. W. (1978b). Influence of growth rate and nutrient limitation on the gross cellular composition of Pseudomonas aeruginosa and its resistance to 3- and 4-chlorophenol. Journal of Bacteriology 133, 1066-1072.

Hodges, N. A. \& Brown, M. R. W. (1975). Properties of Bacillus megaterium spores formed under conditions of nutrient limitation. In Spores VI, pp. 550554. Edited by P. Gerhardt, R. N. Costilow \& H. L. Sadoff. Washington, D.C.: American Society for Microbiology.

HOLME, T. (1972). Influence of environment on the content and composition of bacterial envelope. Journal of Applied Chemistry and Biotechnology 22, 391399.

KRUEGER, W. B. \& KolodzieJ, B. J. (1977). Divalent cation mobility throughout exponential growth and sporulation of Bacillus megaterium. Microbios 18, 159-168.

LAWER, J. V. \& MAIER, S. (1977). Correction for the inherent error in optical density readings. Applied and Environmental Microbiology 33, 482-484.

LEE, Y. H. \& BROWN, M. R. W. (1975). Effect of nutri- 
ent limitation on sporulation of Bacillus stearothermophilus. Journal of Pharmacy and Pharmacology 22 (Suppl.), 22p.

LoNG, S. K. \& Williams, O. B. (1958). Method for removal of vegetative cells from bacterial spore preparations. Journal of Bacteriology 76, 332-337.

MeERS, J. L. \& Tempest, D. W. (1970). The influence of growth-limiting substrate and medium $\mathrm{NaCl}$ concentration on the synthesis of magnesium-binding sites in the walls of Bacillus subtilis var. niger. Journal of General Microbiology 63, 325-331.

NiERLICH, D. P. (1978). Regulation of bacterial growth, RNA, and protein synthesis. Annual Review of Microbiology 32, 393-432.

Rowe, J. J., GoldberG, I. D. \& Amelunten, R. E. (1975). Development of defined and minimal media for the growth of Bacillus stearothermophilus. Journal of Bacteriology 124, 279-284.

STAHL, S. (1978). Calcium uptake and survival of Bacillus stearothermophilus. Archives of Microbiology 119, 17-24.

Sterlini, J. M. \& Mandelstam, J. (1969). Commitment to sporulation in Bacillus subtilis and its relationship to the development of actinomycin resistance. Biochemical Journal i13, 29-37.

TEMPEST, D. W. (1969). Quantitative relationship between inorganic cations and anionic polymers in growing bacteria. Symposia of the Society for General Microbiology 19, 87-111.

VASANTHA, N.\& Freese, E. (1979). The role of manganese in growth and sporulation of Bacillus subtilis. Journal of General Microbiology 112, 329-336. 